\title{
One-pot synthesis of 2-substituted 4H-3,1-benzoxazin-4-one derivatives under mild conditions using iminium cation from cyanuric chloride/dimethylformamide as a cyclizing agent
}

Mehdi Shariat ${ }^{1,2^{*}}$, Mohd Wahid Samsudin ${ }^{1}$ and Zuriati Zakaria ${ }^{3}$

\begin{abstract}
Background: The derivatives of 2-substituted 4H-3,1-benzoxazin-4-one belong to a significant category of heterocyclic compounds, which have shown a wide spectrum of medical and industrial applications.

Results: A new and effective one-pot method for the synthesis of 2-substituted 4H-3,1-benzoxazin-4-one derivatives is described in this paper. By using the iminium cation from a mixture of cyanuric chloride and dimethylformamide as a cyclizing agent, a series of 2-substituted 4H-3,1-benzoxazin-4-one derivatives was synthesized in high yield under mild conditions and simple workup.

Conclusions: The iminium cation from a mixture of cyanuric chloride and $\mathrm{N}, \mathrm{N}$-dimethylformamide is an effective cyclizing agent for the room temperature one-pot synthesis of 2-substituted 4H-3,1-benzoxazin-4-one derivatives in high yields through a cyclodehydration reaction. Furthermore, the method was performed under mild conditions characterized by simplified pathways and workup, minimized energy, and fewer reaction steps, compared with the previous methods. The proposed method, which is a simpler alternative than the published methods, is applicable for the synthesis of other 2-substituted 4H-3,1-benzoxazin-4-one derivatives.
\end{abstract}

Keywords: Iminium cation, Benzoxazinone, Cyclizing agent, Cyclodehydration

\section{Background}

The derivatives of 2-substituted 4H-3,1-benzoxazin-4one belong to a significant category of heterocyclic compounds that have shown a wide spectrum of medical and industrial applications. Some of them are used as an elastase inhibitor [1-3], anti-neoplastic agent, enzyme inhibitor [4], protease inhibitor, and fungicidal [5]. In addition, they are used as a starting material for the preparation of 2,3-disubstituted 4(3H)-quinazolinone derivatives, which are known to have medicinal properties.

The majority of the reported methods for producing 2 -substituted benzoxazin-4-one formula 2 are based on the preparation of $\mathrm{N}$-acylated anthranilic acid derivative

\footnotetext{
* Correspondence: sm.shariat@yahoo.com

'School of Chemical Science and Food Technology, Faculty of Science and Technology, University Kebangsaan Malaysia (UKM), 43600, Selangor, Malaysia ${ }^{2}$ Department of Chemistry, Faculty of Science, Payame Noor University of Golpayegan (PNU), 87117-43153, Isfahan, Iran

Full list of author information is available at the end of the article
}

formula 1 as an intermediate from anthranilic acid derivatives and a chloride of a carboxylic acid (Scheme 1).

The benzoxazin-4-one ring is formed from intermediate formula $\mathbf{1}$ and cyclizing agents, such as acetic anhydride [6-9], polyphosphoric acid [10], sulfuric acid [11], and pyridine [12], which can convert the $\mathrm{OH}$ of the carboxylic acid group into a good living group $\mathbf{W}$ to form the benzoxazin-4-one ring (Scheme 2).

Optimizing the previous methods or designing new routes according to the principles of green chemistry for the synthesis and workup of $4 H$-3,1-benzoxazin-4-one derivatives are essential given the increasing application of this group of fused heterocyclic compounds.

Green chemistry provides an interesting approach for the preparation and application of chemical compounds. This approach is presented as a set of twelve principles $[13,14]$. From the standpoint of green chemistry, chemists should establish a group of parameters for the ideal 

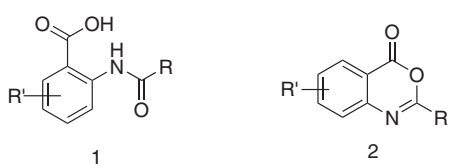

$\mathrm{R}=$ alkyl, aryl

$\mathrm{R}^{\prime}=$ alkyl, aryl, $\mathrm{x}(\mathrm{F}, \mathrm{Cl}, \mathrm{Br}, \mathrm{l})$

Scheme $1 \mathrm{~N}$-acylated anthranilic acid and 2-substituted-4H-3,1benzoxazin-4-one.

chemical synthesis design [14]. A simple pathway and workup, minimized energy, higher yield, lower reagent loss, and fewer reaction steps are among the important parameters in a green chemical pathway. Following this approach, the proposed method for the synthesis of 2-substituted-4H-3,1-benzoxazin-4-one derivatives under mild conditions is an attempt to design a greener reaction.

In this research, a series of 2-substituted-4H-3,1benzoxazin-4-one derivatives was synthesized using the iminium cation from a mixture of cyanuric chloride and dimethylformamide as an effective cyclizing agent as well as the solvent as a catalyst, without the traditional heating or microwave irradiation.

Cyanuric chloride is a commercially available reagent that is commonly used by organic chemists. Numerous articles and reviews have reported various applications of cyanuric chloride in ordinary organic reactions. One of the common applications of cyanuric chloride is the conversion of carboxyl groups into active esters for the preparation of nitrile, acyl azide, ester, amide, and acyl chloride from carboxylic acid derivatives $[15,16]$. Furthermore, cyanuric chloride is used to prepare alkyl chlorides from alcohols [17], amides from ketoximes [18], nitrile from aldoxime [19], isonitrile from formamide [20], disulfide from dimethylsulfoxide [21], and cyclic lactones [22]. In addition, the mixture of cyanuric chloride and dimethylformamide is used as a new organic reagent for the conversion of a broad sequence of secondary and primary alcohols to the corresponding alkyl chlorides and iodides [23,24]. Various ketoximes prepared from the related ketones undergo the Beckmann rearrangement upon reaction with a mixture of cyanuric chlo- ride/dimethylformamide [24]. Moreover, the mixture of cyanuric chloride/dimethylformamide is used for the conversion of $\beta$-amino alcohols to the corresponding chlorides [25].

\section{Results and discussions}

A series of 2-substituted 4H-3,1-benzoxazine-4-one formulae $\mathbf{2 a - i}$ was prepared in good yield at room temperature using anthranilic acid and nine different derivatives of acyl chloride and benzoyl chloride as starting materials as well as iminium cation as cyclizing agent in dimethylformamide in the presence of triethylamine (Table 1).

During the reaction, $\mathrm{N}$-acylated anthranilic acid is produced as an intermediate $\mathbf{1}$ from anthranilic acid and a chloride of alkyl or aryl carboxylic acid in the presence of triethylamine as the $\mathrm{HCl}$ scavenger via $N$-acylation reaction. Given the special structure of $N$-acylated anthranilic acid, benzoxazin-4-one ring can be formed by the intramolecular nucleophilic attack in intermediate 1. However, this process is not generally thought of as viable because of the low electrophilicity of the amide group. Instead, the cyclization reaction can be performed to induce the conversion of carboxylic acid group in $N$-acylated anthranilic acid into an active ester using a cyclizing agent and traditional heating or microwave irradiation. In this research, the iminium cation from a mixture of cyanuric chloride and dimethylformamide acted as a cyclizing agent at room temperature. The 2-substituted 4H-3,1-benzoxazin-4-one derivatives were prepared at room temperature and ambient pressure under mild conditions (Scheme 3).

The positive charge, size, and planar skeleton of the iminium cation make it an easy target for the $\mathrm{OH}$ group, which could result in the production of activated ester in a short time with good yield. However, the stability of benzoxazin-4-one ring provides an appropriate condition for a mild cyclodehydration reaction as the result of the cyclization reaction and the role of dimethylformamide as a good living group in the cyclizing step.

In published papers and reviews, acetic anhydride is commonly used as a cyclizing agent for the synthesis of benzoxazin-4-one derivatives because it can be used in simpler conditions compared with the other known cyclizing agents. However, the use of this compound as a cyclizing agent has several disadvantages. For example,

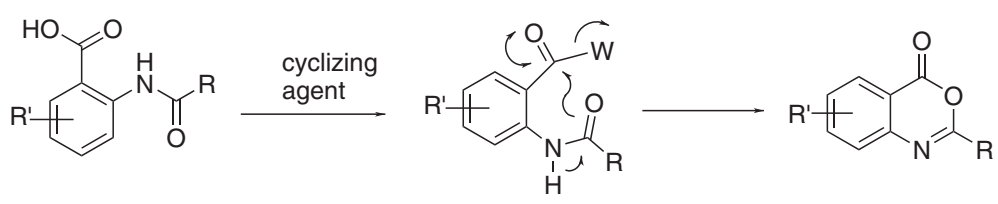

Scheme 2 Formation of the benzoxazin-4-one rings. 
Table 1 Products, yields, and melting points related to Scheme 3

\begin{tabular}{llccc}
\hline No. & Product & $\begin{array}{c}\text { Yield } \\
(\%)\end{array}$ & $\begin{array}{c}\mathrm{mp} \\
\left(\mathrm{T} /{ }^{\circ} \mathrm{C}\right)\end{array}$ & $\begin{array}{c}\text { Lit. } \mathrm{mp} \\
\left(\mathrm{T} /{ }^{\circ} \mathrm{C}\right)\end{array}$ \\
\hline $2 \mathrm{a}$ & 86 & $123-124$ & $123-125[26]$
\end{tabular}

$2 b$<smiles>O=c1oc(-c2cc([N+](=O)[O-])cc([N+](=O)[O-])c2)nc2ccccc12</smiles>

2c<smiles>O=c1oc(-c2ccco2)nc2ccccc12</smiles>

$2 d$<smiles>O=c1oc(-c2ccoc2)nc2ccccc12</smiles>

$2 e$<smiles>O=C1c2ccccc2C(=O)N1Cc1nc2ccccc2c(=O)o1</smiles>

$2 f$<smiles>O=c1oc(-c2ccc(Br)cc2)nc2ccccc12</smiles>

$2 g$

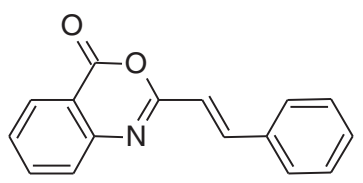

$2 \mathrm{~h}$

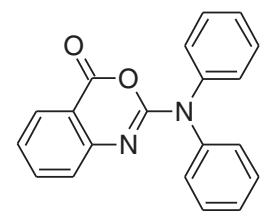

$2 \mathbf{i}$

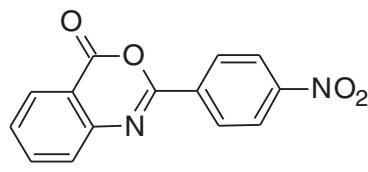

$89 \quad 236-238$

$78 \quad 106-108$

$79 \quad 89-91$

$82 \quad 261-263$

$89 \quad 184-185 \quad 184-185[27,28]$

$80 \quad 148-149 \quad 147-148[29]$

$83 \quad 167-168$

$86 \quad 202-204 \quad 203[27]$ acetic anhydride normally works as a cyclizing agent through traditional heating or microwave irradiation. In addition, this compound is listed as a United State Drug Enforcement Administration (U. S. DEA List II precursor), and restricted in numerous countries. On the contrary, the iminium cation can be a good cyclizing agent in cyclodehydration reactions because it can be used at room temperature with commercially available cyanuric chloride and dimethylformamide.

\section{Conclusions}

The iminium cation obtained from a mixture of cyanuric chloride and $\mathrm{N}, \mathrm{N}$-dimethylformamide is an effective reagent for the room temperature one-pot synthesis of 2substituted 4H-3,1-benzoxazin-4-one derivatives in high yields through cyclodehydration. The proposed method can be performed under mild conditions, with simplified pathways and workup, minimized energy, and fewer reaction steps, compared with the reported methods. Moreover, this method is applicable for the synthesis of other 2-substituted 4H-3,1-benzoxazin-4-one derivatives.

\section{Methods \\ General}

The structures of products $\mathbf{2} \mathbf{a}-\mathbf{i}$ were confirmed by analysis using spectral data $\left({ }^{1} \mathrm{H}-\mathrm{NMR},{ }^{13} \mathrm{C}-\mathrm{NMR}\right.$, FT-IR and HRMS). All spectral data and spectrum are represented in Additional file 1. The FT-IR spectra were measured by using $\mathrm{KBr}$ pellets. The NMR spectra were recorded on $600 \mathrm{MHz}$ spectrometer and chemical shifts are reported relative to TMS. The mass spectra were recorded using a TOF-Q instrument was operated in positive ion mode. The melting points were measured in open capillary tubes without correction. All commercial reagents were synthesis grade and were used as received without additional purification. The procedures for preparation and purification of reported products are the same.

\section{Preparation of 2-phenyl-4H-3,1-benzoxazin-4-one (2a)}

Benzoyl chloride $(0.349 \mathrm{ml}, 3 \mathrm{mmol})$ was added to a stirred solution of anthranilic acid $(0.411 \mathrm{~g}, 3 \mathrm{mmol})$ and triethylamine $(0.460 \mathrm{~mL}, 3.3 \mathrm{mmol})$ in chloroform $(10 \mathrm{~mL})$. The mixture was stirred at room temperature for 2 hours, then, a yellow light colour solution of Cyanuric chloride $(0.553 \mathrm{~g}, 3 \mathrm{mmol})$ in DMF $(5 \mathrm{~mL})$ was added to the stirred mixture. After 4 hours, the solvent was evaporated in vacuum and the residual was poured into distilled water $(20 \mathrm{~mL})$ and ice. Then, the filtrated solids were washed with a saturated solution of $\mathrm{NaHCO}_{3}$ (10 mL, two times) and distilled water (two times, 25 $\mathrm{mL}$ each). The white precipitate was recrystallized from a 1:1 diethyl ether/ethanol mixture to give the fine needle crystal of 2a $\left(0.578\right.$ gr, yield: $\left.86 \%, \mathrm{mp}: 123-124^{\circ} \mathrm{C}\right)$. IR (KBr): $v_{\max } / \mathrm{cm}^{-1} 1764,1622,1603,1541,1266,1077$. 
${ }^{1} \mathrm{H}-\mathrm{NMR}$ (DMSO): $\delta \mathrm{ppm} 8.20$ (ddd, $J=7.2,1.2,0.6 \mathrm{~Hz}$, $2 \mathrm{H}$ ), 8.15 (ddd, $J=7.2,1.2,0.6 \mathrm{~Hz} 1 \mathrm{H}$ ), 7.95 (tdd, $J=8.4$, 7.2, $1.2 \mathrm{~Hz}, 1 \mathrm{H}), 7.59-7.73(\mathrm{~m}, 5 \mathrm{H}) .{ }^{13} \mathrm{C}-\mathrm{NMR}$ (DMSO): $159.4,156.8,146.7,137.3,133.2,130.5,129.5,129.1$, $128.5,128.3,127.4,117.4$. HRMS (ESI-TOF) $m / z$ : $[\mathrm{M}+\mathrm{H}]^{+}$Calcd for $\mathrm{C}_{14} \mathrm{H}_{10} \mathrm{NO}_{2}$ (224.0707); Found 224.0706.

Preparation of 2-(3,5-dinitrophenyl)-4H-3,1-benzoxazin-4one (2b)

3,5-dinitrobenzoyl chloride $(0.692 \mathrm{gr}, 3 \mathrm{mmol})$ is used for preparation of $\mathbf{2} \mathbf{b}$ using the same procedure as $\mathbf{2 a}$. The sea-urchin shaped crystal was prepared (0.839 gr, yield: $89 \%$, mp: $236-238^{\circ} \mathrm{C}$ ) from crystallization of the gray powder of $\mathbf{2 b}$ in 1:1 ether/ethanol. IR (KBr): $v_{\max } / \mathrm{cm}^{-1} 1776$, 1622, 1603, 1541, 1473, 1266, 1077. ${ }^{1} \mathrm{H}-\mathrm{NMR}$ (DMSO): $\delta$ ppm 9.13 (dd, $J=1.8,1.2 \mathrm{~Hz}, 2 \mathrm{H}), 9.04$ (dd, $J=1.4,1.2 \mathrm{~Hz}$, $1 \mathrm{H}), 8.23$ (ddd, $J=7.8,1.2,0.6 \mathrm{~Hz}, 1 \mathrm{H}), 8.02$ (ddd, $J=8.4$,
7.8,1.2 Hz, 1H), 7.90 (ddd, $J=7.8,1.2,0.6 \mathrm{~Hz}, 1 \mathrm{H}$ ) and 7.73 (ddd, $J=8.4,7.8,1.2 \mathrm{~Hz}, 1 \mathrm{H}) .{ }^{13} \mathrm{C}-\mathrm{NMR}$ (DMSO): 158.6, 153.6, 149.1, 145.9, 137.7, 133.7, 130.2, 128.8, 127.9, 127.6, 122.1, 117.8. HRMS (ESI-TOF) $m / z:[\mathrm{M}+\mathrm{H}]^{+}$Calcd for $\mathrm{C}_{14} \mathrm{H}_{8} \mathrm{~N}_{3} \mathrm{O}_{6}$ (314.0408); Found 314.0390.

Preparation of 2-(furan-2-yl)-4H-3,1-benzoxazin-4-one (2c) For preparation of 2c, 2-Furoyl chloride was used by using the same procedure, as $\mathbf{2 a}$. The product was isolated as a white crystalline solid (0.500 gr, yield: $78 \%$, $\left.\mathrm{mp} 106-108^{\circ} \mathrm{C}\right)$. IR (KBr): $v_{\max } / \mathrm{cm}^{-1} 1753,1683,1604$, 1557, 1256, 1011. ${ }^{1} \mathrm{H}-\mathrm{NMR}$ (DMSO, $\delta \mathrm{ppm}$ ): 8.12 (ddd, $J=7.8,1.2,0.6 \mathrm{~Hz}, 1 \mathrm{H}), 8.09$ (dd, $J=0.6,1.8 \mathrm{~Hz}$, $1 \mathrm{H}), 7.93$ (ddd, $J=0.6,1.2,7.8 \mathrm{~Hz}, 1 \mathrm{H}), 7.66$ (ddd, $J=$ 7.8, 1.2, $7.8 \mathrm{~Hz}, 1 \mathrm{H}$ ), 7.59 (ddd, $J=7.8,1.2,7.8 \mathrm{~Hz}$, $1 \mathrm{H}), 7.45(\mathrm{dd}, J=3.6,0.6 \mathrm{~Hz}, 1 \mathrm{H}), 6.80(\mathrm{dd}, J=1.8,3.6$ $\mathrm{Hz}, 1 \mathrm{H}) .{ }^{13} \mathrm{C}-\mathrm{NMR}$ (DMSO): 158.7, 149.6, 148.4, 146.7, $144.6,137.4,128.8,128.6,127.1,117.5,113.4$. HRMS 
(ESI-TOF) $m / z:[\mathrm{M}+\mathrm{H}]^{+}$Calcd for $\mathrm{C}_{12} \mathrm{H}_{8} \mathrm{NO}_{3}$ (214.0499); Found 214.0497.

Preparation of 2-(furan-3-yl)-4H-3,1-benzoxazin-4-one (2d) 3-Furoyl chloride was used for preparation $\mathbf{2 d}$ and the product was isolated as a white crystalline solid (0.506 gr, yield: 79\%, mp 89-91 ${ }^{\circ} \mathrm{C}$ ). IR (KBr): $v_{\max } /$ $\mathrm{cm}^{-1} 1764,1644,1632,1603,1258,1069 .{ }^{1} \mathrm{H}-\mathrm{NMR}$ (DMSO, $\delta \mathrm{ppm}): 8.55(\mathrm{dd}, J=1.8,0.6 \mathrm{~Hz}, 1 \mathrm{H}), 8.16$ (ddd, $J=7.8,1.2,0.6 \mathrm{~Hz}, 1 \mathrm{H}), 7.92(\mathrm{ddd}, J=7.8,1.2$, $0.6 \mathrm{~Hz}, 1 \mathrm{H}), 7.89$ (dd, $J=1.8,1.2 \mathrm{~Hz}, 1 \mathrm{H}), 7.64$ (ddd, $J=7.8,1.2,0.6 \mathrm{~Hz}, 1 \mathrm{H}), 7.59$ (ddd, $J=7.4,7.2,1.2$ $\mathrm{Hz}, 1 \mathrm{H}), 7.00$ (dd, $J=1.8,0.6 \mathrm{~Hz}, 1 \mathrm{H}) .{ }^{13} \mathrm{C}-\mathrm{NMR}$ (DMSO): 159.2, 153.5, 147.4, 146.7, 145.9, 137.4, $128.8,128.6,126.93,119.8,117.3,109.2$. HRMS (ESITOF) $m / z:[\mathrm{M}+\mathrm{H}]^{+}$Calcd for $\mathrm{C}_{12} \mathrm{H}_{8} \mathrm{NO}_{3}$ (214.0499); Found 214.0478.

\section{Preparation of 2-( $\mathrm{N}$-phthaloylmethyl)-4H-3,1-benzoxazin-} 4-one (2e)

Benzoxazinone 2e was prepared from phthalimidoacetyl chloride $(0.671 \mathrm{gr}, 3 \mathrm{mmol})$ the same procedure as above and product was collected as a light yellow crystalline solid (0.752 gr, yield: $\left.82 \%, \mathrm{mp} 261-263^{\circ} \mathrm{C}\right)$. IR (KBr): $v_{\max } / \mathrm{cm}^{-1}$ 1776, 1688, 1591, 1529, 1258, 1088. ${ }^{1} \mathrm{H}-\mathrm{NMR}$ (DMSO): $\delta$ ppm 7.89-8.08 (m, $5 \mathrm{H}, \mathrm{Ar}-\mathrm{H}$ ), 7.87 (ddd, $J=7.8,1.2,0.6$ $\mathrm{Hz} 1 \mathrm{H}, \mathrm{Ar}-\mathrm{H}$ ), 7.60 (ddd, $J=7.8,1.2,6.6 \mathrm{~Hz}, 1 \mathrm{H}, \mathrm{Ar}-\mathrm{H}$ ), 7.23 (ddd, $J=6.6,7.2,1.2 \mathrm{~Hz}, 1 \mathrm{H}, \mathrm{Ar}-\mathrm{H}$ ), 3.77 (s, $2 \mathrm{H}$, $\mathrm{CH}_{2}$ ). ${ }^{13} \mathrm{C}-\mathrm{NMR}$ (DMSO): 167.9, 167.8, 165.7, 138.6, 135.2, 134.2, 132.0, 131.0, 124.5, 124.4, 122.3, 119.8, 52.7. HRMS (ESI-TOF) $m / z$ : $[\mathrm{M}+\mathrm{H}]^{+}$Calcd for $\mathrm{C}_{17} \mathrm{H}_{11} \mathrm{~N}_{2} \mathrm{O}_{4}$ (307.0713); Found 307.0720.

\section{Preparation of 2-(4-bromophenyl)-4H-3,1-benzoxazin-4- one (2f)}

Final product was isolated as a crystalline solid (0.802 gr, yield: $\left.89 \%, \mathrm{mp}: 184-185^{\circ} \mathrm{C}\right)$. IR (KBr): $v_{\max } / \mathrm{cm}^{-1} 1762$, 1619, 1602, 1586, 1256, 1067. ${ }^{1} \mathrm{H}-\mathrm{NMR}$ (DMSO): $\delta \mathrm{ppm}$ 8.16 (ddd, $J=7.2,1.2,0.6 \mathrm{~Hz}, 1 \mathrm{H}$ ), 8.11 (ddd, $J=6.6,1.8$, $0.6 \mathrm{~Hz}, 2 \mathrm{H}), 7.96$ (ddd, $J=8.4,7.2,1.2 \mathrm{~Hz}, 1 \mathrm{H}), 7.81$ (ddd, $J=6.0,1.2,0.6 \mathrm{~Hz}, 2 \mathrm{H}$ ), 7.73 (ddd, $J=8.4,1.2,0.6$ $\mathrm{Hz}, 1 \mathrm{H})$ and 7.64 (ddd, $J=7.8,7.2,0.6 \mathrm{~Hz}, 1 \mathrm{H}) .{ }^{13} \mathrm{C}-$ NMR (DMSO): 159.2, 156.2, 154.1, 137.4, 132.6, 130.2, $129.8,129.2,128.6,127.4,127.1,117.5$. HRMS (ESITOF) $m / z:[\mathrm{M}+\mathrm{H}]^{+}$Calcd for $\mathrm{C}_{14} \mathrm{H}_{9} \mathrm{BrNO}_{2}$ (301.9811); Found 301.9807.

\section{Preparation of 2-(styryl)-4H-3,1-benzoxazin-4-one (2g)}

The product was collected as a yellow crystalline solid (0.600 gr, yield: $80 \%$, mp: $\left.148-149^{\circ} \mathrm{C}\right)$. IR (KBr): $v_{\max } / \mathrm{cm}^{-1}$ 1761, 1635, 1592, 1566, 1251, 1040. ${ }^{1}$ H-NMR (DMSO): $\delta$ ppm 7.78 (d, $J=16.2 \mathrm{~Hz}, 1 \mathrm{H}), 7.59-8.16$ (m, 9H, Ar-H), 7.01 (d, $J=16.2 \mathrm{~Hz}, 1 \mathrm{H}) .{ }^{13} \mathrm{C}-\mathrm{NMR}$ (DMSO): 159.2, 157.3, 147.1, 141.6, 137.3, 134.9, 130.8, 129.4, 128.9, 128.7, 128.5,
127.1, 119.7, 117.3. HRMS (ESI-TOF) $m / z:[\mathrm{M}+\mathrm{H}]^{+}$Calcd for $\mathrm{C}_{16} \mathrm{H}_{12} \mathrm{NO}_{2}$ (250.0863); Found 250.0851.

\section{Preparation of 2-(diphenylamino)-4H-3,1-benzoxazin-4- one (2h)}

The result was isolated as a crystalline solid (83\% yield, 0.780 gr, mp: $\left.167-168^{\circ} \mathrm{C}\right)$. IR (KBr): $v_{\max } / \mathrm{cm}^{-1} 1745,1619$, 1582, 1489, 1267, 1072. ${ }^{1} \mathrm{H}-\mathrm{NMR}$ (DMSO): $\delta \mathrm{ppm} 7.93$ (ddd, $J=8.4,1.8,0.6 \mathrm{~Hz}, 1 \mathrm{H}$ ), 7.69 (ddd, $J=8.4,7.2,1.8$ $\mathrm{Hz}, 1 \mathrm{H}$ ), 7.42-7.45 (m, 8 H, Ar-H), 7.29 - 7.32 (m, 2H, Ar$\mathrm{H}), 7.26$ (ddd, $J=7.8,7.2,0.6 \mathrm{~Hz}, 1 \mathrm{H}), 7.16$ (ddd, $J=7.8$, 1.2, $0.6 \mathrm{~Hz}, 1 \mathrm{H}) .{ }^{13} \mathrm{C}-\mathrm{NMR}$ (DMSO): 159.4, 153.1, 150.1, 142.7, 137.2, 128.5, 129.7, 128.0, 127.2, 125.1, 124.9, 114.1. HRMS (ESI-TOF) $m / z$ : $[\mathrm{M}+\mathrm{H}]^{+}$Calcd for $\mathrm{C}_{20} \mathrm{H}_{15} \mathrm{~N}_{2} \mathrm{O}_{2}$ (315.1128); Found 315.1131.

\section{Preparation of 2-(4-nitrophenyl)-4H-3,1-benzoxazin-4-one} (2i)

The procedure 2a was used for synthesis and workup of 2-(4-nitrophenyl)-4H-3,1-benzoxazin-4-one and the final product was gathered as a yellow wish crystalline solid (0.779 gr, yield: $86 \%$, mp: 202-204). IR (KBr): $v_{\max } / \mathrm{cm}^{-1}$ 1766, 1607, 1589, 1522, 1493, 1251, 1082. ${ }^{1} \mathrm{H}-\mathrm{NMR}$ (DMSO): $\delta$ ppm 8.43 (ddd, $J=6.6,1.8,0.6 \mathrm{~Hz}, 2 \mathrm{H}$ ), 8.39 (ddd, $J=0.6,7.8,1.1 \mathrm{~Hz}, 1 \mathrm{H}$ ), 8.18 (ddd, $J=0.6,7.2,1.2$ $\mathrm{Hz}, 2 \mathrm{H}$ ), 8.00 (ddd, $J=7.8,1.2,0.6 \mathrm{~Hz}, 1 \mathrm{H}$ ), 7.71 (ddd, $J=$ 8.4, 1.2, 7.2 Hz, 1H), 7.30 (ddd, $J=7.2,7.8,0.6 \mathrm{~Hz}, 1 \mathrm{H}$ ). ${ }^{13}$ C-NMR (DMSO): 159.0, 156.2, 150.3, 146.7, 137.4, $136.4,130.1,129.8,128.6,127.2,125.4,119.1$. HRMS (ESI-TOF) $m / z:[\mathrm{M}+\mathrm{H}]^{+}$Calcd for $\mathrm{C}_{14} \mathrm{H}_{9} \mathrm{~N}_{2} \mathrm{O}_{4}$ (269.0557); Found 269.0554.

\section{Additional file}

Additional file 1: The spectral data $\left({ }^{1} \mathrm{H}-\mathrm{NMR},{ }^{13} \mathrm{C}-\mathrm{NMR}, \mathrm{FT}-\mathrm{IR}\right.$ and HRMS) for products $2 a-i$ are represented in Additional file 1.

\section{Competing interests}

This research focused on an application of iminium cation, namely, as a cyclizing agent in the cyclodehydration reaction under mild conditions. Iminium cation may be usable in other reactions in this category. In addition, the role of dimethylformamide was interesting because it acted as a catalyst.

\section{Authors' contributions}

MS proposed the subject, designed the study, helped in the results and discussion, and carried out the synthesis of all the products. MWS and ZZ conceived the study and participated in its design, results and discussion, and coordination, as well as helped draft the manuscript. All the authors read and approved the final manuscript.

\section{Acknowledgements}

The authors thank the technical assistants and coordinators of the analytical laboratories of Faculty of Science and Technology (FST), University Kebangsaan Malaysia (UKM).

\section{Author details}

${ }^{1}$ School of Chemical Science and Food Technology, Faculty of Science and Technology, University Kebangsaan Malaysia (UKM), 43600, Selangor, Malaysia. ${ }^{2}$ Department of Chemistry, Faculty of Science, Payame Noor 
University of Golpayegan (PNU), 87117-43153, Isfahan, Iran. ${ }^{3}$ Malaysia Japan International Institute of Technology, University Technology Malaysia (UTM), 54100, Kuala Lumpur, Malaysia.

Received: 27 January 2013 Accepted: 18 March 2013

Published: 27 March 2013

\section{References}

1. Peet NP, Angelastro MR, Burkhart JP: Novel orally-active elastase inhibitors. In Book Novel orally-active elastase inhibitors. Edited by. Munich, Germany: European Patent Office; 1997. EP Patent 0,529,568.

2. Colson $E$, Wallach J, Hauteville $M$ : Synthesis and anti-elastase properties of 6-amino-2-phenyl-4<i $>\mathrm{H}</ \mathrm{i}>-3$, 1-benzoxazin-4-one aminoacyl and dipeptidyl derivatives. Biochimie 2005, 87:223-230.

3. Oshida J, Kawabata H, Kato Y, Kokubo M, Uejima Y, Sato O, Fujii K: 4H-3, 1benzoxazin-4-one compound and elastase inhibitor composition containing the same. In Book 4H-3, 1-benzoxazin-4-one compound and elastase inhibitor composition containing the same. Edited by; 1992. EP Patent 0,466,944

4. Krantz A, Spencer R, Tam T: 4H-3, 1-benzoxazin-4-ones and related compounds and use as enzyme inhibitors. In Book 4H-3, 1-benzoxazin-4ones and related compounds and use as enzyme inhibitors. Edited by. U.S. Patent and Trademark Office: Washington, DC; 1987. U.S. Patent No. 4,657,893.

5. Besson T, Rees CW, Cottenceau G, Pons AM: Antimicrobial evaluation of 3, 1-benzoxazin-4-ones, 3, 1-benzothiazin-4-ones, 4-alkoxyquinazolin-2carbonitriles and $<\mathrm{i}>\mathrm{N}</ \mathrm{i}>-$ arylimino-1, 2, 3-dithiazoles. Bioorg Med Chem Lett 1996, 6:2343-2348.

6. Connolly DJ, Cusack D, O'Sullivan TP, Guiry PJ: Synthesis of quinazolinones and quinazolines. Tetrahedron 2005, 61:10153-10202.

7. Elgohary AMF, Hassan MM, Abass M: Synthesis of some quinazolin-4-one derivatives carrying ibuprofenyl moiety and their antiinflammatory activity. Der Pharma Chemica 2011, 3:1-12.

8. Azarifar D, Sheikh D: Ultrasound-Promoted Catalyst-Free Synthesis of 2,2'(1,4-Phenylene)bis[1-acetyl-1,2-dihydro-4H-3,1-benzoxazin-4-one] Derivatives. Helv Chim Acta 2012, 95:1217-1225.

9. Alagarsamy V: Synthesis and pharmacological investigation of some novel 2-methyl-3-(substituted methylamino)-(3H)-quinazolin-4-ones as histamine H1-receptor blockers. Die Pharmazie - An International Journal of Pharmaceutical Sciences 2004, 59:753-755.

10. Kurihara M, Saito H, Nukada K, Yoda N: Cyclopolycondensation. XII. Polymerization mechanism of polybenzoxazinones in polyphosphoric acid medium. J Polym Sci [A1] 1969, 7:2897-2914.

11. Papadopoulos EP, Torres CD: Convenient preparation of $\mathrm{N}$-substituted 2amino-4H-3, I-benzoxazin-4-ones and 3-substituted 2,4(1H,3H)quinazolinediones. J Heterocycl Chem 1982, 19:269-272.

12. Eissa AMF, El-Sayed R: Synthesis and evaluation of condensed and noncondensed heterocyclic compounds of industrial application. J Heterocycl Chem 2006, 43:1161-1168.

13. Anastas P, Eghbali N: Green chemistry: principles and practice. Chem Soc $\operatorname{Rev} 2010,39: 301-312$.

14. Poliakoff M, Anastas P: Green chemistry: a principal stance. Nature 2001, 413:257-258.

15. Bandgar B, Pandit S: Synthesis of acyl azides from carboxylic acids using cyanuric chloride. Tetrahedron Lett 2002, 43:3413-3414

16. Venkataraman $\mathrm{K}$, Wagle D: Cyanuric chloride: a useful reagent for converting carboxylic acids into chlorides, esters, amides and peptides. Tetrahedron Lett 1979, 20:3037-3040.

17. Hamon F, Prié G, Lecornué F, Papot S: Cyanuric chloride: an efficient reagent for the Lossen rearrangement. Tetrahedron Lett 2009, 50:6800-6802

18. Maia A, Albanese DCM, Landini D: Cyanuric chloride catalyzed Beckmann rearrangement of ketoximes in biodegradable ionic liquids. Tetrahedron 2012, 68:1947-1950.

19. Akhlaghinia B, Roohi E: Efficient method for tetrahydropyranylation of phenols and alcohols using 2, 4, 6-trichloro [1,3,5] triazine. Turk J Chem 2007, 31:83-88.

20. Porcheddu A, Giacomelli G, Salaris M: Microwave-assisted synthesis of isonitriles: a general simple methodology. J Org Chem 2005, 70:2361-2363.

21. De Luca $L$, Giacomelli $G$, Porcheddu A: A mild and efficient alternative to the classical swern oxidation. J Org Chem 2001, 66:7907-7909.
22. Venkataraman $\mathrm{K}$, Wagle DR: Cyanuric chloride, a useful reagent for macrocyclic lactonization. Tetrahedron Lett 1980, 21:1893-1896.

23. Hullio AA, Mastoi GM: Application of multipurpose dimethylformamidelike task specific ionic liquid as a recyclable reagent for direct iodination of alcohols. Iranian Journal of Catalysis 2011, 1(2):79-86.

24. De Luca L, Giacomelli G, Porcheddu A: Beckmann rearrangement of oximes under very mild conditions. J Org Chem 2002, 67:6272-6274.

25. De Luca L, Giacomelli G, Porcheddu A: An efficient route to alkyl chlorides from alcohols using the complex TCT/DMF. Org Lett 2002, 4:553-555.

26. Thilagavathy R, Kavitha HP, Arulmozhi R, Vennila JP, Manivannan V: 2Phenyl-4H-3,1-benzoxazin-4-one. Acta Crystallogr Sect E- Struct Rep 2009, 65:0127.

27. Khajavi MS, Shariat SM: A New Synthesis of 2-Substituted 4H-3,1Benzoxazin-4-ones by Cyanuric Chloride Cyclodehydration of $\mathrm{N}$-Benzoyland N-Acylanthranilic Acids. Heterocycles 2005, 65:1159-1165.

28. Bain DI, Smalley R: Synthesis of 2-substituted-4H-3, 1-benzoxazin-4-ones. J Chem Soc C 1968, 0:1593-1597.

29. Jagani CL, Vanparia SF, Patel TS, Dixit RB, Dixit BC: A comparative study of solution phase as well as solvent free microwave assisted syntheses of 3-benzothiazole/isoxazole substituted 2-styryl-4 (3H)-quinazolinones. Arkivoc 2012, 6:281-294.

doi:10.1186/1752-153X-7-58

Cite this article as: Shariat et al:: One-pot synthesis of 2-substituted 4H-3,1-benzoxazin-4-one derivatives under mild conditions using iminium cation from cyanuric chloride/dimethylformamide as a cyclizing agent. Chemistry Central Journal 2013 7:58.

Publish with ChemistryCentral and every
scientist can read your work free of charge
"Open access provides opportunities to our
colleagues in other parts of the globe, by allowing
anyone to view the content free of charge."
W. Jeffery Hurst, The Hershey Company.
- available free of charge to the entire scientific community
- peer reviewed and published immediately upon acceptance
- cited in PubMed and archived on PubMed Central
- yours - you keep the copyright
submit your manuscript here:
http://www.chemistrycentral.com/manuscript/

